\title{
SABERESFAZERES EM EDUCAÇÃO - POR ENTRE PROCESSOS FORMATIVOS E PRÁTICAS DOCENTES
}

Caríssimos/as Leitores/as,

Em meio aos desafios intensos que estamos vivenciando, especialmente nos tempos mais recentes, reflexões profundas e cuidadosas se fazem mais do que necessárias. São tempos em que o ritmo da produção precisa dialogar, mais do que nunca, com o tempo e com o compasso (seria ritmo?) da vida. "Viver é muito perigoso", já nos disse Riobaldo, personagem de Guimarães Rosa em Grande sertão: Veredas.

Vivemos um momento em que a vida é o bem mais importante a cuidarmos e a buscarmos formas de bem (e melhor) viver. Nesse contexto, precisamos descobrir novas formas de lidar com o cotidiano e, na escola, não foi diferente. Nossos saberesfazeres em educação precisaram se redimensionar e provavelmente precisem assim permanecer por mais um tempo... São formas outras de viver e de construir os saberesfazeres docentes que tornam viver um pouco menos perigoso.

É nesse cenário de tantas mudanças, inovações e criações desafiadoras que nasce a edição 22 de e-Mosaicos. Nesta edição, os saberesfazeres em educação trazem para a cena diferentes e múltiplas dimensões que provocam o pensar sobre a educação de jovens e adultos e a educação profissional, além do pensar sobre a formação docente em diferentes potencialidades e seus processos formativos. Ganham corpo também as práticas docentes, em diferentes áreas e contextos e as formas de interação com a extensão universitária.

Esse mosaico composto por 25 produções se inicia com Denise Santos e Natália Almeida discutindo a modalidade educação de jovens e adultos como política pública municipal, bem como a sua evolução, considerando uma experiência inovadora em São Paulo. Em seguida, O PROEJA baiano apresenta o debate da educação profissional e da educação de jovens e adultos retomando-se os conceitos de ensino integrado e de educação profissional pelas palavras de Jocemara Santos e de José Humberto da Silva.

Dando continuidade, o terceiro artigo nos permite refletir sobre o trabalho com conceitos científicos em sala de aula a partir de uma análise da Língua Brasileira de Sinais, seus usos e desafios que se apresentam, sobretudo na área de exatas.

O quarto artigo apresenta a formação de professores de Sociologia pelo/no Instituto de Aplicação da Uerj, articulando ensino, pesquisa e extensão universitária. Na sequência, o artigo seguinte também traz a perspectiva da formação docente a partir da Matemática.

Natacha Bastos e Rogério Lima analisam "Quarto de despejo: diário de uma favelada", de Carolina Maria de Jesus, como obra que potencializa a reflexão sobre relações de opressão.

Dentro da perspectiva da produção escrita, o sexto e sétimo artigos possibilitam refletir sobre: a importância da produção escrita em turma de aceleração de aprendizagem em escola pública do município de São Gonçalo (RJ) e a alfabetização em turma de $3^{\circ}$ ano do Ensino Fundamental a partir de experiência do município de Santos (SP).

A seguir, a brincadeira entra em cena em dois artigos. O oitavo, permite-nos refletir sobre a relevância das brincadeiras para o desenvolvimento infantil, ao passo que o nono artigo versa sobre as práticas educativas com crianças da favela da Maré, localizada na zona norte do Rio de Janeiro, possibilitando o diálogo sobre a potência da ludicidade em 
diferentes espaços sociais e educativos. Em seguida, Bianca Chisté e Catiane Souza analisam as "percepções, sentidos e sensações de professoras da Educação Infantil" a partir de pesquisa de Iniciação Científica desenvolvida em Roraima.

O ensino de Ciências é temática que perpassa os artigos décimo ao décimo sexto, contemplando: um levantamento de periódicos da área; a experiência vivenciada no Programa Institucional de Bolsas de Iniciação à Docência (PIBID) na Universidade Estadual do Paraná; um repensar sobre a arquitetura escolar com foco nas condições destinadas aos laboratórios da área de Ciências, por meio de um olhar sobre escolas públicas dos anos iniciais em Cascavel (PR); as formas de compreensão do mundo natural nas relações de produção por meio do conhecimento científico, a partir das Diretrizes Curriculares Estaduais do Paraná; a ficção científica e sua relação com o ensino de Ciências a partir de Star Wars; os conhecimentos sobre a leishmaniose e a presença desse estudo em livros didáticos de Biologia e, fechando esse bloco temático, as percepções de estudantes do Ensino Médio sobre os efeitos da automedicação, a partir de ação desenvolvida por meio de projeto de extensão universitária.

O décimo sétimo artigo traz para o debate interações discursivas produzidas em uma ação de formação docente por meio de diálogos entre estagiária de curso de licenciatura em Química e estudantes de Ensino Médio.

Marcelo Matos apresenta a importância do trabalho com esportes alternativos em aulas de Educação Física, a partir de trabalho desenvolvido junto a estudantes do quinto ano de escolaridade do Ensino Fundamental do CAp-Uerj, sendo este mais um diálogo com a perspectiva da formação docente.

As artes visuais entram em cena por meio do Laboratório das Memórias e das Práticas Cotidianas da Universidade Estadual Vale do Aracaú, em Sobral (CE), com Nilson de Freitas apresentando a articulação entre a extensão universitária, cultura e antropologia.

Encerrando nosso grande mosaico de temas tão plurais e representativos do tripé ensino, pesquisa e extensão universitária que compõem a gênese do conceito de universidade, a experiência do Instituto Federal do Norte de Minas Gerais é retratada por meio de análise de indicadores de produtividade apresentando os desafios da extensão universitária na região do norte de Minas Gerais.

E assim, por meio dos textos que compõem as sessões Artigos e Relatos de Experiências, buscamos trazer a pluralidade, a diversidade e as diferentes formas em que os saberesfazeres da educação se constituem, por vezes metamorfoseadamente, mais em diálogos que representam, nas/pelas diversas regiões brasileiras, ricas potencialidades de processos formativos e de práticas docentes. Processos e práticas esses que merecem nosso reconhecimento permanente e, sobretudo por estarmos em Outubro, os cumprimentos a todos os professores e professoras brasileiros e do mundo que fazem a diferença na formação da humanidade. E que sabem o quanto é valioso ensinaraprender a viver! De forma menos perigosa e com mais sensibilidade na escuta atenta de cada um que, seja do lugar de estudante ou de profissional da educação (porque todos somos educadores) constróem cotidianamente saberesfazeres.

Boa leitura e parabéns, Professores e Professoras!

Andrea da Paixão Fernandes e Lincoln Tavares Silva

Editores Gerais - e-Mosaicos 